\title{
UTICAJ STIMULATIVNIH MERA NA MOTIVACIJU PRIPADNIKA VOJSKE SRBIJE
}

\author{
Milan Kovačević \\ Generalštab Vojske Srbije \\ Srđan Blagojević \\ Univerzitet odbrane u Beogradu, Vojna akademija \\ Bojan Kuzmanović \\ Generalštab Vojske Srbije
}

Motivacija je od izuzetnog značaja u organizacijama posebne name-

ne kakva je vojska. U Vojsci Srbije, u cilju podizanja nivoa motivisanosti njenih pripadnika ustanovljen je i normativno uređen sistem dodele stimulativnih mera (nagrada). Njime su utvrđeni vrste i način dodele nagrada.

Praksa je pokazala da dosledna primena propisanih odredbi može da ima značajan uticaj na motivaciju pripadnika Vojske Srbije. Dosledna primena podrazumeva objektivan, jasan i transparentno realizovan proces dodele nagrada i ispoljava jako motivaciono dejstvo na sve pripadnike organizacije. Međutim, određena iskustvena opažanja ukazuju na pojavu da nivo uticaja dodele nagrada u poslednjem periodu nije adekvatan i da ne doprinosi značajno dostizanju željenog nivoa motisanosti pojedinaca i kolektiva. Razlozi za to mogu biti brojni, a cilj našeg rada bio je da identifikujemo neke od bitnh razloga.

$U$ radu su prikazani rezultati istraživanja stavova 393 profesionalna pripadnika Vojske Srbije o motivacionom uticaju stimulativnih mera. Podaci su prikupljeni ispitivanjem stavova o uticaju dodele stimulativnih mera na motivaciju za rad, uticaju stimulativnih mera na motivaciju za rad i radne rezultate u organizaciji, stavova o načinu dodele i o zasluženosti dodeljenih stimulativnih mera. Takođe je utvrđena i prikazana rang lista stimulativnih mera (nagrada) u Vojsci Srbije, kao i razlike u rangiranju stimulativnih mera i razlike u stavovima različitih grupa ispitanika (oficir-podoficir, visoka-srednja stručna sprema, rukovodioci-izvršioci) čije je postojanje utvrđeno primenom Opštenaučne statističke metode i njoj bliskih instrumenata.

Ključne reči: motivacija, motivacija za rad, stimulativne mere, rangiranje

Uvod

7 načaj pokretačke snage za razvoj čoveka i svih njegovih delatnosti je veliki. U njenom nedostatku intelektualni i fizički kapaciteti čoveka mogu ostati neiskorišćeni.

U cilju zadovoljenja identifikovanih ljudskih potreba dolazi do aktivacije unutrašnjih ili spoljnih podsticaja od kojih zavisi upotreba raspoložive energije i trajanje aktivnosti. 
Nije teško uočiti da zaposleni koji poseduju slične sposobnosti mogu postizati veoma različite rezultate. Otkrivanje i objašnjavanje snaga i mehanizama koji pokreću čoveka da aktivira svoje sposobnosti i znanja pruža velike mogućnosti praktične primene u organizaciji i van nje. Zbog toga je važno utvrditi faktore koji utiču na povećanje radnog angažovanja zaposlenog, kao i odnose i veze koji vladaju među njima.

Uzimajući u obzir činjenicu da organizacija može uticati na svoje rezultate uticajem na motivaciju zaposlenih za rad, te da se tim uticajem može postići mnoštvo pozitivnih efekata, proces motivacije zaposlenih predstavlja značajan predmet istraživanja. Rezultati do kojih se dođe mogu poslužiti za donošenje raznih strategija motivisanja zaposlenih što svakako doprinosi ostvarivanju boljih radnih rezultata.

Potrebno je istaći da je ovo vrlo kompleksna oblast, te da je veliki broj autora pokušao da ponudi odgovore na pitanja o motivaciji i faktorima motivacije - kroz različite teorije motivacije. Specifičnosti lične, ali i sredinske zavisnosti motivacije za rad nameću potrebu konkretizacije određenih problema. Ustanovljeno je da se brojni problemi ne mogu rešavati opštim matricama jer ono što važi za jednu organizaciju ne mora da važi za drugu, odnosno principi utvrđeni u jednom kolektivu ne moraju biti primenjivi u svim drugim radnim sredinama i situacijama.

Problem radne motivacije je aktuelan za sve organizacije, pa tako i vojnu. Istraživanja motivacionih činilaca koji imaju najveći uticaj na radno angažovanje profesionalnih pripadnika Vojske Srbije može poslužiti u razvoju motivacionih strategija i tehnika, jer se ne može pretpostavljati danas kao pre više decenija da je samim tim što je pripadnik Vojske zaposleni i ujedno visoko motivisan. S obzirom da je dodela stimulativnih mera jedan od bitnih načina razvoja motivacije kod pripadnika Vojske Srbije cilj našeg rada bio je da prikažemo stavove profesionalnih pripadnika Vojske Srbije o načinu i pravednosti dodele i motivacionom potencijalu stimulativnih mera. Posebnu pažnju u radu posvetili smo utvrđivanju stimulativnih mera koje imaju najveći uticaj na radnu motivaciju profesionalnih pripadnika Vojske Srbije kako bi smo preispitali postojeće načine praktikovanja.

U radu je za prikupljanje podataka primenjena metoda naučnog ispitivanja, u okviru kojeg je primenjena tehnika ankete. Dobijeni podaci obrađeni su standardnim postupcima parametrijske i neparametrijske statistike (utvrđivanje aritmetičke sredine, standarde devijacije, zakrivljenost i spljoštenost distribucije). Za utvrđivanje statističke značajnosti utvrđenih razlika korišćeni su t-test i $H^{2}$ test, a za rangiranje je korišćena agregacija normalizovane sume rangova.

\section{Sistem nagrađivanja i stimulativne mere u Vojsci Srbije}

Deklarativno, pitanju motivacije zaposlenih i adekvatnom nagrađivanju u Vojsci Srbije posvećena je značajna pažnja, što se vidi i kroz projektovane prioritetne zadatke razvoja upravljanja ljudskim resursima za period 2011-2015. godine, kao i za period 2016-2020. godine. Jedan od zadataka ogleda se u potrebi: „obezbediti kvalitetan i motivisan kadar na svim dužnostima [1]. "Činjenica je da je ovaj zadatak teško postići u uslovima kada „socijalni status zaposlenih karakteriše realno smanjenje zarada, nerešena stambena pitanja, neprepoznavanje značaja i specifičnosti vojnog poziva u društvu“ [2].

Za razliku od deklarativne zainteresovanosti za pitanje motivacije ovo kompleksno i veoma važno pitanje je u praksi čini se nedovoljno razmatrano. U prilog tome govori činjenica da ne postoje razrađeni mehanizmi praćenja i merenja nivoa motivacije, izuzev praćenja pojedinih činilaca motivacije koji su sadržani u upitnicima za procenu morala. 
U praksi se mogu identifikovati određeni problemi u shvatanju značaja sistema nagrađivanja za postignute rezultate. Iskustveno se mogu opaziti situacije da sistem nagrađivanja pokazuje određene manjkavosti koje se prevashodno odnose na nedovoljan uticaj na motivaciju zaposlenih. Po inerciji prošlog vremena i prošlih vrednosnih sistema često kod vojnih rukovodilaca vlada uverenje da je pripadnik Vojske Srbije nužno motivisan za rad i odbranu zemlje samim tim što se opredelio za rad u njenoj službi. Takođe često se nepravilno poistovećuju motivacija za rad zaposlenih i borbeni moral ili motivacija za odbranu i odnos prema odbrani otadžbine. Odnos prema odbrani otadžbine i slobodarskim tradicijama našeg naroda je i nakon transformacije Vojske Srbije i značajnih društveno-ekonmomskih promena i dalje na visokom nivou, činjenica je da je zauzeti sistem vrednosti uglavnom stabilan i da promene se odvijaju u dužem vremenskom periodu [3]. Međutim, stepen pripremljenosti za odbranu zavisi od rezultata rada zaposlenih u Vojsci Srbije i sistemu odbrane, a njihovi rezultati i od motivisanosti za rad čime motivacija za rad profesionalnih pripadnika direktno utiče na spremnost da se brani i odbrani otadžbina.

Sistem nagrađivanja je doktrinarno i normativno uređen: "Sistem nagrađivanja uspostavlja vezu između rada i zarade, stimuliše kvalitetne pripadnike i motiviše dobar i kvalitetan rad. Sistem nagrađivanja je veoma sveobuhvatan i sastoji se od direktnih nadoknada (plate, stimulacije i dr.) i indirektnih nadoknada (zdravstveno, penzijsko i invalidsko osiguranje, stipendije, godišnji odmori, slobodni dani i dr.)". [4]

Normativno sistem nagrađivanja je uređen i regulisan Zakonom o Vojsci Srbije ${ }^{1}$, Pravilnikom o platama ${ }^{2}$, Uredbom o radnom vremenu, odmorima i odsustvima profesionalnih vojnih lica ${ }^{3}$ i Pravilnikom o priznanjima i nenovčanim nagradama. ${ }^{4}$ Nagrade koje pripadnik Vojske može dobiti su na prvi pogled brojne i vredne (novčana nagrada, nagradno odsustvo, besplatan boravak u odmaralištu, oficirska sablja, paradni bodež, ručni sat, dvogled, ručna busola, knjiga, pohvala), ali je pitanje koliki uticaj imaju na motivaciju za rad. ${ }^{5}$

Sistem nagrađivanja je pravilno koncipiran, ima određenih nedostataka pre svega u maloj raznovrsnosti nagrada, ali više problema stvara neadekvatna primena i bitno mu smanjuje motivaciono dejstvo. Za razliku od disciplinskih mera i kazni koje se redovno izriču po „zasluzi“, nagrade se dodeljuju u ograničenom obimu i po pravilu za državne i vojne praznike. Postoji i problem cirkulacije nagrada do najnižih nivoa, jer je način dodele pojedinih nagrada visoko centralizovan, tako da se pripadnici na „periferiji“ retko razmatraju za dodelu najznačajnijih i najpoželjnijih nagrada.

Dozvoljeni nivo novčanih nagrada u iznosu do $100 \%$ plate je takođe u praksi napušten delom zbog ograničenih novčanih sredstava, a delom radi unificiranja prilikom dodele nagrada po organizacionim nivoima, gde dolazi do ograničavanja nagrada na nižem nivou. Takođe, 2017. godine umesto decentralizacije novčanih nagrada dolazi do nove centralizacije i ograničenja, tako da je trenutno za dodelu novčanih nagrada nadležan isključivo ministar odbrane.

Nagrađivanje u krug i po redosledu kao i uvek istih lica, obesmišljava nagrade, a neretko se nagrade dodeljuju na taj način i to smanjuje njihov motivacioni potencijal.

\footnotetext{
${ }^{1}$ Službeni glasnik RS br. 116/2007, 88/2009, 101/2010 - dr. zakon, 10/2015 i 88/2015 - odluka US.

${ }^{2}$ Službeni vojni list br. 10/17 - prečišćen tekst, 13/17 i 37/17.

${ }^{3}$ Službeni vojni list br. 35/09.

${ }^{4}$ Službeni vojni list br. 22/2012, 10/2013, 13/16 i 13/17.

${ }^{5}$ Od nabrojanih nagrada oficirska sablja, paradni bodež, ručni sat, dvogled i ručna busola dodeljuju se samo licima povodom zaveršetka školovanja-usavršavanja i imaju uticaj na motivaciju za postizanje uspeha na školovanju-usavršavanju, ali nemaju uticaj na motivaciju za rad.
} 
Metod

Realizovano istraživanje je zasnovano na statističkoj opštenaučnoj metodi, korišćenjem naučnog ispitivanja kao metode istraživanja, u okviru kojeg je primenjena anketa kao tehnika prikupljanja podataka.

Upitnik koji je razvijen i apliciran u istraživanju ima sledeće celine:

- uputstvo za popunjavanje i obraćanje istraživača,

- pitanja zatvorenog tipa koja se odnose na podatke o ispitanicima (kategorija kadra, podaci o dostignutom nivou školovanja, uloga u organizaciji),

- pitanja koja se odnose na procenu uticaja stimulativnih mera na motivaciju i stavove o uticaju stimulativnih mera na motivaciju u organizaciji i o načinu i pravednosti dodele stimulativnih mera (Likertova petostepena skala),

- pitanja u kojima ispitanici treba da rangiraju stimulativne mere (10 stimulativnih mera), lista ponuđenih stimulativnih mera nastala je kombinovanjem važećih i projektovanih.

Značajnost razlika u stavovima o uticaju stimulativnih mera na motivaciju, uticaju stimulativnih mera na motivaciju u kolektivu i zadovoljstvom dodele stimulativnih mera utvrđena je primenom dvosmernog t-testa za velike nezavisne uzorke (test se primenjuje na dva različita uzorka, broj ispitanika je veći od 30). Da bi se odbacila nulta hipoteza (nema statistički značajne razlike između aritmetičkih sredina dva uzorka) potrebno je da vrednost t bude veća od granične vrednosti za nivo značainosti od $5 \%$ (za steben slobode u zavisnosti od veličine uzorka).

Radi izračunavania vrednost $t$ potrebno je prethodno utvrditi vrednost standardne greške razlika aritmetičke sredine koja se dobija na osnovu sledeće relacije [4]:

$$
S_{M 1-M 2}=\sqrt{S_{M 1}^{2}}+S_{M 2}^{2}=\sqrt{\frac{S D_{1}^{2}}{N_{1}}+\frac{S D_{2}^{2}}{N_{2}}}
$$

pri čemu je $N$ broj ispitanika (veličina uzorka), a $S D$ - standardna devijacija koja se računa primenom sledećeg izraza

$$
S D=\sqrt{\frac{\sum(X-\bar{X})^{2}}{N-1}}
$$

Razlika aritmetičkih sredina podeljena vrednošću standardne greške aritmetičkih sredina daje vrednost $t$ :

$$
t=\frac{\mathrm{M}_{1}-\mathrm{M}_{2}}{\mathrm{~S}_{\mathrm{M} 1-\mathrm{M} 2}}
$$

Nakon izračunavania vrednosti $t$ potrebno je u tablicama proveriti značajnost u zavisnosti od utvrđenog stepena slobode $(d f)$ :

$$
d f(\text { stepeni slobode })=(N 1-1)+(N 2-1)
$$

i ako je dobijena vrednost $t$ manja od granične vrednosti prihvatamo nultu hipotezu (nema statistički značajne razlike između aritmetičkih sredina dva uzorka), a ako je vrednost 
$t$ veća od granične vrednosti - nultu hipotezu odbacujemo (utvrđene razlike aritmetičkih sredina su statistički značajne).

Uslov za korišćenje opisane parametrijske statističke metode je da je raspodela uzorka koii se ispituie normalna te ie potrebno ispitati karakteristike uzorka. odnosno da li su dozvolienom opseau. za ovu proveru koriste se funkcije skjunis i kurtosis (Skewness $-g$; Kurtosis - $k$ ), prema izrazima (1.5) [6] i (1.6) [7].

$$
\begin{aligned}
& g=\frac{\sum_{\mathrm{i}=1}^{\mathrm{n}}\left(\mathrm{x}_{\mathrm{i}}-\overline{\mathrm{x}}_{1}\right)}{(\mathrm{n}-1) \mathrm{S}^{3}} \\
& k=\frac{\sum_{\mathrm{i}=1}^{\mathrm{n}}\left(\mathrm{x}_{\mathrm{i}}-\overline{\mathrm{x}}\right)}{(\mathrm{n}-1) \mathrm{S}^{4}}
\end{aligned}
$$

pri čemu je n veličina uzorka, S standardna devijacija, a $\bar{x}$ srednja vrednost uzorka.

Značajnost razlika u stavovima o pravednoj dodeli stimulativnih mera i načinu dodele stimulativnih mera, utvrđena je $H^{2}$ (chi-square) testom, ovaj neparametrijski test koristi se kada se radi sa frekvencijama, odnosno kada podaci koje posedujemo nisu podobni za upotrebu parametrijskih testova. Računanje $h^{2}$ vrši se po sledećem izrazu [8]:

$$
\mathrm{x}^{2}=\sum \frac{\left(\mathrm{f}_{\mathrm{o}}-\mathrm{f}_{\mathrm{t}}\right)^{2}}{\mathrm{f}_{\mathrm{t}}}
$$

pri čemu fo predstavlja opažene frekvencije, a ft očekivane (teoretske) frekvencije.

Rangiranje stimulativnih mera je realizovano metodom aritmetičkog osrednjavanja [9] primenom izraza (1.8) i (1.9) tako što je suma dobijenih rangova normalizovana, a zatim je izvršena konverzija u agrerirane težine.

$$
\begin{aligned}
W_{j} & =\frac{\sum_{i=1}^{m} W_{i, j}}{m} \quad J=1, \ldots, n \\
W_{i, j} & =100-s_{n}\left(r_{i, j}-1\right) i=1, \ldots, m, j=1, \ldots, n
\end{aligned}
$$

\section{Realizacija istraživanja i rezultati}

Istraživanje je realizovano u toku 2010. godine na prigodnom uzorku od 393 profesionalnih pripadnika Vojske Srbije (190 oficira, 128 podoficira, 55 civilnih lica i 20 profesionalnih vojnika). Detaljna struktura ispitanika po kategorijama, ulozi u organizaciji i stručnoj spremi prikazana je u Tabeli 1. 
Tabela 1 - Podaci o uzorku

\begin{tabular}{|l|c|c|c|c|c|}
\hline \multicolumn{7}{|c|}{ Podaci o uzorku } \\
\hline \multicolumn{2}{|c|}{ Kategorija } & Izvršioci & Rukovodioci & SSS $^{6}$ & VSS $^{7}$ \\
\hline Oficiri & 190 & 109 & 81 & 0 & 190 \\
\hline Podoficiri & 128 & 98 & 30 & 122 & 6 \\
\hline Civilna lica & 55 & 55 & 0 & 25 & 30 \\
\hline Profesionalni vojnici & 20 & 18 & 2 & 19 & 1 \\
\hline \multicolumn{1}{|c|}{ UKUPNO } & $\mathbf{3 9 3}$ & $\mathbf{2 8 0}$ & $\mathbf{1 1 3}$ & $\mathbf{1 6 6}$ & $\mathbf{2 2 7}$ \\
\hline
\end{tabular}

Nakon prikupljanja i obrade podataka utvrđene su statističke vrednosti za uzorak: srednje vrednosti, standardna devijacija, asimetričnost (Skewness) i homogenost (Kurtosis), za uzorak (tabela 2) po pitanjima kojima su mereni stavovi ispitanika putem skale Likertovog tipa (ponuđeni odgovori o stepenu uticaja: ni malo, malo, umereno, mnogo, veoma mnogo).

Tabela 2 - Stavovi o uticaju stimulativnih mera na motivaciju

\begin{tabular}{|l|c|c|c|c|}
\hline \multicolumn{1}{|c|}{ STAVOVI } & M & SD & Sk & Ku \\
\hline 1. Uticaj stimulativnih mera na motivaciju za rad & 3,42 & 1,116 & $-0,464$ & $-0,255$ \\
\hline $\begin{array}{l}\text { 2. Uticaj stimulativnih mera na motivaciju za rad i radne } \\
\text { rezultate u kolektivu }\end{array}$ & 2,58 & 1,104 & 0,145 & $-0,793$ \\
\hline $\begin{array}{l}\text { 3. Stimulativne mere dobijaju lica koja su radom i } \\
\text { rezultatima to i zaslužila }\end{array}$ & 2,94 & 1,105 & $-0,125$ & $-0,538$ \\
\hline
\end{tabular}

Napomena: Sk = skewness, Ku = kurtosis. Vrednost standardne greške Sk je 0,123, a za Ku je 0,246.

Dobijeni rezultati-srednje vrednosti za uzorak za pitanja Uticaj stimulativnih mera na motivaciju za rad (AS -3,42) i Uticaj stimulativnih mera na motivaciju za rad i radne rezultate $u$ kolektivu (AS -2,58) ukazuju na nizak uticaj stimulativnih mera na motivaciju za rad.

Primenom t-testa (prema izrazu 1.3) ${ }^{8}$ utvrđeno je da nema statistički značajnih razlika u aritmetičkim sredinama za oficire-podoficire, SSS-VSS i rukovodioce-izvršioce u odnosu na ocene tvrdni Uticaj stimulativnih mera na motivaciju za rad i Uticaj stimulativnih mera na motivaciju za rad i radne rezultate u kolektivu [10]. Pre primene t-testa utvrđeno je da je raspodela uzorka po pitanjima koja se ispituju normalna, korišćenjem funkcije skjunis (Skewness) za asimetričnost i kurtosis (Kurtosis) za homogenost, prema izrazima (1.5) i (1.6). Primenom programa IBM SPSS Statistic 23 može se i grafički-vizuelno oceniti oblik distribucije, prikaz se vidi na grafikonu 1.

\footnotetext{
${ }^{6}$ SSS (srednja stručna sprema) lica za srednjom stručnom spremom i niže.

${ }^{7}$ VSS (visoka stručna sprema) lica sa minimalno visokom stručnom spremom, uključena su i lica sa poslediplomskim školovanjima i usavršavanjima.

${ }^{8}$ Vrednost $\boldsymbol{t}$ može se izračunati navedenim izrazom, a takođe postoje odgovarajući programi i kalkulatori.
} 


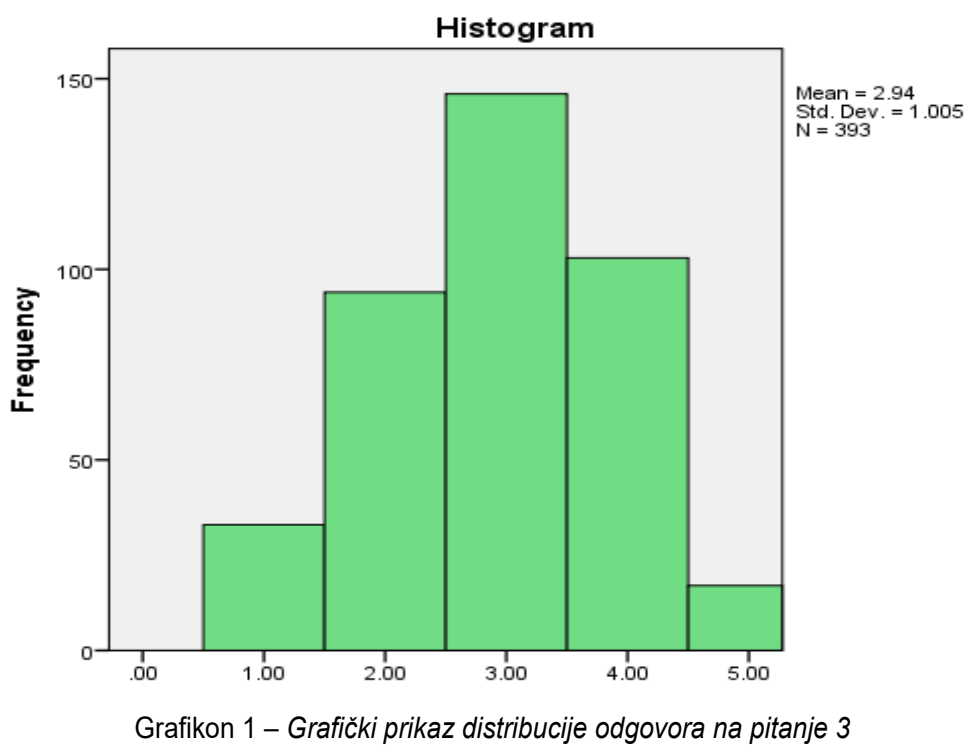

Međutim stavovi po pitanju Stimulativne mere dobijaju lica koja su radom i rezultatima to i zaslužila imaju značajno nižu vrednost (AS -2,94) što ukazuje na manjkavosti u načinu izbora lica kojima se stimulativne mere dodeljuju. Po ovom pitanju utvrđene su statistički značajne razlike na nivou $p<0,01$ (tabela 3 ).

- oficiri-podoficiri: vrednost t-iznosi 5,7985 (stavovi oficira u odnosu na zasluženost stimulativnih mera koje se dodeljuju su pozitivniji od stavova podoficira),

- VSS i SSS: vrednost t - iznosi 4,3829 (stavovi lica sa VSS u odnosu na zasluženost stimulativnih mera koje se dodeljuju su pozitivniji od stavova lica sa SSS).

Statistički značajne razlike u odnosu na ulogu u organizaciji (rukovodilac-izvršilac) za ovo pitanje nisu utvrđene.

Tabela 3 - t-test statističke značajnosti razlika: oficiri-podoficiri i VSS-SSS ${ }^{9}$

\begin{tabular}{|l|c|c|c|c|c|}
\hline $\begin{array}{l}\text { Stimulativne mere dobijaju lica koja su radom i } \\
\text { rezultatima to i zaslužila }\end{array}$ & M & SD & N & df & t \\
\cline { 1 - 5 } Oficiri & 3,1789 & 0,8846 & 190 & \multirow{2}{*}{243} & \multirow{2}{*}{5,798} \\
\cline { 1 - 5 } Podoficiri & 2,5313 & 1,0699 & 128 & & \\
\cline { 1 - 5 } VSS & 3.1322 & 0,9024 & 227 & \multirow{2}{*}{317} & \multirow{2}{*}{4,383} \\
\cline { 1 - 4 } SSS & 2,6807 & 1,0789 & 166 & & \\
\hline
\end{tabular}

Napomena: $\mathrm{N}=$ broj ispitanika, $\mathrm{df}=$ stepeni slobode (degrees of freedom)

\footnotetext{
${ }^{9}$ Primenjen kalkulator: https://www.mathportal.org/calculators/statistics-calculator/t-test-calculator.php
} 
Rezultati - frekvencije stavova ispitanika o zasluženosti dodeljenih stimulativnih mera i o načinu na koji se dodeljuju stimulativne mere, prikazani su za kompletan uzorak u tabeli 4 i tabeli 5 . Primetno je da veći procenat ispitanika $(37,6 \%)$ ima negativne stavove 0 dodeli stimulativnih mera (dobijaju ih oni koji nisu zaslužili $27,2 \%$ i nisu stimulativne i za njih se ne vredi truditi $10,4 \%$ ) dok $19,3 \%$ ispitanika ima pozitivne stavove (veliki uticaj na motivaciju za rad 17,8\% i veoma mnogo me motivišu 1,5\%). Neutralan stav ima 43,0\% ispitanika (nemaju značajan uticaj na motivaciju za rad).

Tabela 4 - Stavovi o zasluženosti dodele stimulativnih mera

\begin{tabular}{|l|c|c|}
\hline \multicolumn{1}{|c|}{ 4. Dodela stimulativnih mera se vrši na način } & Frekvencija & $\%$ \\
\hline Dobijaju oni koji ih nisu zaslužili i gubim volju za radom & 107 & $27,2 \%$ \\
\hline Nisu stimulativne - za njih se uopšte ne vredi truditi & 41 & $10,4 \%$ \\
\hline Nemaju značajan uticaj na motivaciju za rad & 169 & $43,0 \%$ \\
\hline Imaju veliki uticaj na motivaciju za rad & 70 & $17,8 \%$ \\
\hline Veoma mnogo me motivišu i daju mi podsticaj za rad & 6 & $1,5 \%$ \\
\hline UKUPNO & 393 & 100,0 \\
\hline
\end{tabular}

Pozitivne stavove u odgovorima na pitanja o načinu dodele stimulativnih mera iskazalo je samo $14,5 \%$ ispitanika (dodeljuju se na predlog kolektiva $4,1 \%$ i dodeljuju se na osnovu rezultata rada $10,4 \%$ ) dok negativne stavove ima čak $46,8 \%$ ispitanika (na osnovu veza i poznanstva $25,4 \%$ i paušalno i po redosledu $21,4 \%$ ). Neutralan stav ima $37,8 \%$ ispitanika (na osnovu ocene pretpostavljenog).

Tabela 5 - Stavovi o načinu dodele stimulativnih mera

\begin{tabular}{|l|r|r|}
\hline \multicolumn{1}{|c|}{ 5. Stimulativne mere se dodeljuju } & \multicolumn{1}{c|}{ Frekvencija } & \multicolumn{1}{c|}{$\%$} \\
\hline Na osnovu rezultata rada & 41 & $10,4 \%$ \\
\hline Na osnovu veza i poznanstva & 100 & $25,4 \%$ \\
\hline Paušalno i po redosledu & 84 & $21,4 \%$ \\
\hline Na osnovu ocene pretpostavljenog & 152 & $38,7 \%$ \\
\hline Na predlog kolektiva & 16 & $4,1 \%$ \\
\hline \multicolumn{1}{|c|}{ UKUPNO } & 393 & 100,0 \\
\hline
\end{tabular}

Pošto prikazani podaci o stavovima ispitanika nisu intervalni, za utvrđivanje statističkih razlika korišćen je $\mathrm{H}^{2}$ (chi-square) test. Ovaj neparametrijski test pogodan je za upotrebu kada se radi sa frekvencijama, odnosno u prilikama kada podaci koje posedujemo nisu podobni za upotrebu parametrijskih testova.

Primenom izraza (1.7) izvršena je provera statističke značajnosti razlika u frekvencijama po kategorijama, stručnoj spremi i ulozi u organizaciji. Uslovi za primenu testa su zadovoljeni 
[5], uzorak ima potreban obim ( $n>30)$, a takođe je izvršeno spajanje susednih ćelija kada je opažena frekvencija bila manja od 5 . Za utvrđenu vrednost $\mathrm{H}^{2}$ utvrđuje se p-vrednost koja predstavlja verovatnoću da se takva ili još veća vrednost dobije u istraživanju pod pretpostavkom da je nulta hipoteza ispravna [8]. Statistički značajne razlike potvrđene su kao i primenom t-testa za različite kategorije kadra i stepen stručne spreme, dok statistički značajnih razlika nije bilo za različite uloge u organizaciji (način dodele: $\mathrm{H}^{2}=2,824, p=0,4188$ i zasluženost dodele: $\left.H^{2}=4,912, p=0,2964\right)$. Rezultati gde su utvrđene statistički značajne razlike dobijeni su upotrebom kalkulatora [11] i prikazani su u Tabeli 6 i Tabeli $7 .{ }^{10}$

Tabela $6-H^{2}$ test - zasluženost stimulativnih mera

\begin{tabular}{|c|c|c|c|c|c|c|}
\hline Stavovi & VSS & sSS & Ukupno & Oficiri & Podof. & Ukupno \\
\hline Nisu zaslužene & 37 & 70 & 107 & 9 & 55 & 64 \\
\hline Nisu stimulativne & 25 & 16 & 41 & 60 & 14 & 74 \\
\hline Nemaju značajan uticaj & 117 & 52 & 169 & 84 & 43 & 127 \\
\hline Imaju veliki uticaj & 48 & 28 & 76 & 37 & 16 & 53 \\
\hline$H^{2}$ & \multicolumn{3}{|c|}{33,$7615 ; p<0,00001$} & \multicolumn{3}{|c|}{73,$9366 ; p<0,00001$} \\
\hline
\end{tabular}

Rezultati ukazuju da ispitanici sa visokom stručnom spremom (VSS) imaju pozitivnije stavove o zasluženosti dodeljenih stimulativnih mera u odnosu ispitanike sa srednjom stručnom spremom (pozitivne stavove ima $21 \%$ VSS i $17 \%$ SSS, a negativne $27 \%$ VSS i $52 \%$ SSS), razlike su izražene i u stavovima oficira i podoficira (pozitivne stavove ima $19 \%$ oficira i $13 \%$ podoficira, a negativne $36 \%$ oficira i $53 \%$ podoficira).

Ispitanici sa visokom stručnom spremom (VSS) imaju neutralnije stavove o načinu dodele stimulativnih mera u odnosu ispitanike sa srednjom stručnom spremom (pozitivne stavove ima $12 \%$ VSS i $17 \%$ SSS, a negativne $40 \%$ VSS i $57 \%$ SSS, neutralne stavove izrazilo je $48 \%$ VSS i $26 \%$ SSS), a stavovi oficira i podoficira su ujednačeni u odnosu na pozitivne i negativne stavove, (pozitivne stavove ima $19 \%$ oficira i $13 \%$ podoficira, a negativne $36 \%$ oficira i $53 \%$ podoficira) ali sa izraženom razlikom u najnegativnijim stavovima (nagrade se dodeljuju na osnovu veze i poznanstva: oficiri $10 \%$, podoficiri $50 \%$ ).

Tabela $7-H^{2}$ test - način dodele stimulativnih mera

\begin{tabular}{|l|c|c|c|c|c|c|}
\hline \multicolumn{1}{|c|}{ Stavovi } & VSS & SSS & Ukupno & Oficiri & Podof. & Ukupno \\
\hline Rezultati rada & 20 & 21 & 41 & 9 & 55 & 35 \\
\hline Veze i poznanstva & 27 & 73 & 100 & 60 & 14 & 84 \\
\hline U krug & 63 & 21 & 84 & 84 & 43 & 122 \\
\hline Ocena pretpostavljenog & 109 & 43 & 152 & & & 68 \\
\hline Predlog kolektiva & 8 & 8 & 16 & 37 & 16 & 9 \\
\hline$H^{2}$ & 62,$8892 ; p<0,00001$ & 84,$419 ; p<0,00001$ \\
\hline
\end{tabular}

\footnotetext{
${ }^{10}$ Primenjen kalkulator: http://www.socscistatistics.com/tests/chisquare2/Default2.aspx
} 
Rangiranje motivacionog uticaja i značaja stimulativnih mera izvršeno tako što su ispitanici dodeljivali rang ponuđenim stimulativnim merama (nagrada knjigom, nagradno odsustvo, upućivanje na školovanje-kurs, vanredno unapređenje, novčana nagrada, pohvala pred strojem, nagrada sabljom ili pištoljem, odlikovanje, besplatan boravak u odmaralištu, raspored na viši položaj). Rezultati rangiranja stimulativnih mera, za kompletan uzorak, po kategorijama kadra, po ulozi u organizaciji i stručnoj spremi prikazani su u Tabeli 8 i na Slici 1 i Slici 2.

Tabela 8 - Rangiranje stimulativnih mera

\begin{tabular}{|c|c|c|c|c|c|c|c|c|c|c|}
\hline \multirow[b]{2}{*}{$\begin{array}{l}\text { KATEGORI- } \\
\text { JA KADRA }\end{array}$} & \multicolumn{10}{|c|}{ STIMULATIVNE MERE } \\
\hline & $\begin{array}{l}\frac{E}{0} \\
\frac{0}{\overline{7}} \\
\frac{\overline{2}}{\pi} \\
\frac{\pi}{0} \\
\frac{\pi}{0} \\
\frac{\pi}{2} \\
\frac{\pi}{2}\end{array}$ & 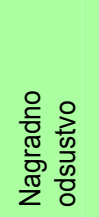 & 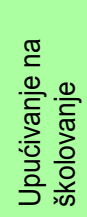 & 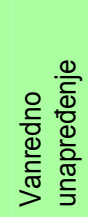 & 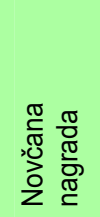 & 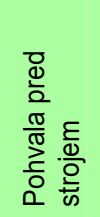 & 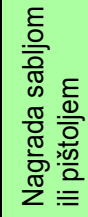 & 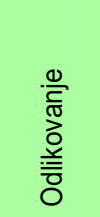 & 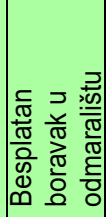 & 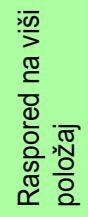 \\
\hline OFICIRI & 0,0623 & 0,0878 & 0,1028 & 0,1145 & 0,1562 & 0,0625 & 0,1025 & 0,0973 & 0,1052 & 0,1089 \\
\hline RANG & 10 & 8 & 5 & 2 & 1 & 9 & 6 & 7 & 4 & 3 \\
\hline PODOFICIRI & 0,0682 & 0,1078 & 0,0956 & 0,1018 & 0,1761 & 0,0677 & 0,1056 & 0,0911 & 0,1046 & 0,0814 \\
\hline RANG & 9 & 2 & 6 & 5 & 1 & 10 & 3 & 7 & 4 & 8 \\
\hline CIV. LICA & 0,0693 & 0,1461 & 0,0978 & 0,0941 & 0,1742 & 0,0646 & 0,0692 & 0,0712 & 0,1258 & 0,0877 \\
\hline RANG & 8 & 2 & 4 & 5 & 1 & 10 & 9 & 7 & 3 & 6 \\
\hline IZVRŠIOCI & 0,0665 & 0,1017 & 0,1005 & 0,1094 & 0,1622 & 0,0653 & 0,0963 & 0,0918 & 0,1108 & 0,0955 \\
\hline RANG & 9 & 4 & 5 & 3 & 1 & 10 & 6 & 8 & 2 & 7 \\
\hline $\begin{array}{l}\text { RUKOVO- } \\
\text { DIOCI }\end{array}$ & 0,0674 & 0,0982 & 0,1043 & 0,1065 & 0,1626 & 0,0681 & 0,1030 & 0,0948 & 0,0997 & 0,0954 \\
\hline RANG & 10 & 6 & 3 & 2 & 1 & 9 & 4 & 8 & 5 & 7 \\
\hline SSS & 0,0703 & 0,1110 & 0,0953 & 0,1038 & 0,1646 & 0,0693 & 0,1005 & 0,0905 & 0,1102 & 0,0845 \\
\hline RANG & 9 & 2 & 6 & 4 & 1 & 10 & 5 & 7 & 3 & 8 \\
\hline VSS & 0,0640 & 0,0938 & 0,1063 & 0,1120 & 0,1601 & 0,0636 & 0,0961 & 0,0940 & 0,1048 & 0,1052 \\
\hline RANG & 9 & 8 & 3 & 2 & 1 & 10 & 6 & 7 & 5 & 4 \\
\hline UKUPNO & 0,0668 & 0,1007 & 0,1016 & 0,1086 & 0,1624 & 0,0661 & 0,0982 & 0,0927 & 0,1074 & 0,0955 \\
\hline RANG & 9 & 5 & 4 & 2 & 1 & 10 & 6 & 8 & 3 & 7 \\
\hline
\end{tabular}

Prikazani rezultati dobijeni su korišćenjem izraza (1.8) i (1.9), postupkom aritmetičkog osrednjavanja sume rangova svih ispitanika, aritmetičke sredine sume rangova su zatim normalizovane i nakon toga je izvršena konverzija u prikazane agregirane težine pri čemu su rangovi utvrđeni od najpoželjnije-najvažnije stimulativne mere (rang 1) do najmanje važne (rang 10). 


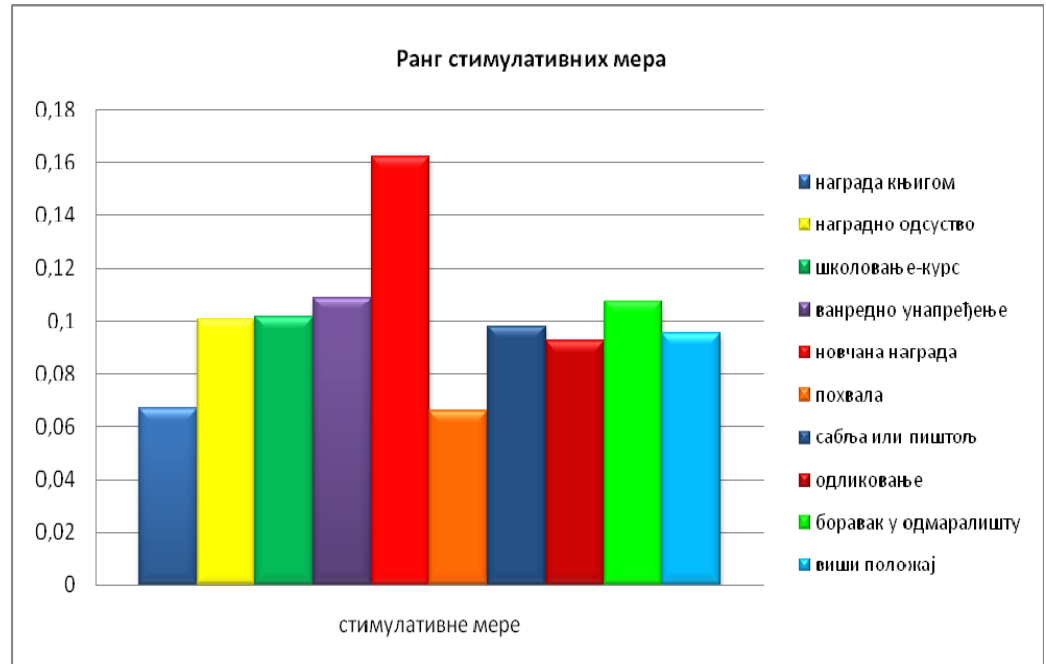

Slika 1 - Rang stimulativnih mera (kompletan uzorak)

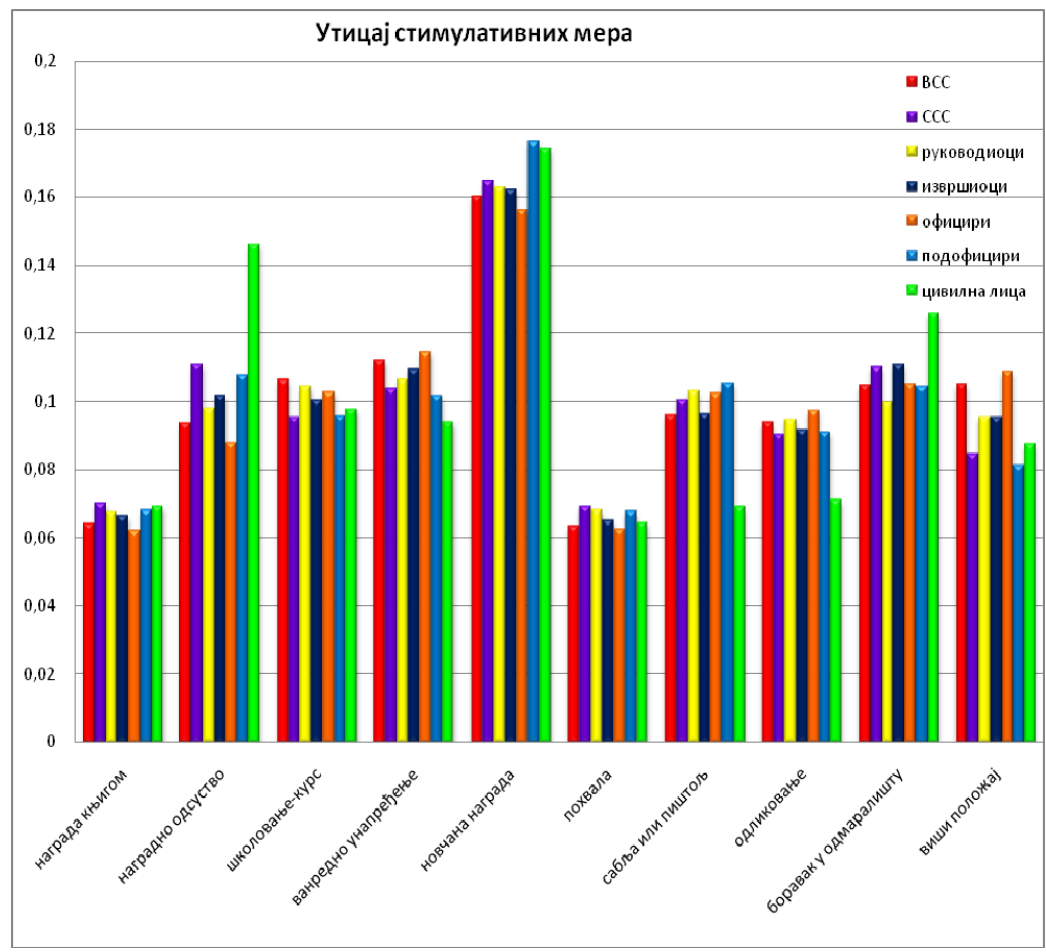

Slika 2 - Rang stimulativnih mera (po grupama) 
Iz dobijenih rezultata vidljivo je da je najpoželjnija stimulativna mera novčana nagrada (rang $1 ; 0,1624$ ) i da je razlika između novčana nagrade i drugih nagrada veoma izražena (vanredno unapređenje, rang 2; 0,1086; besplatan boravak u odmaralištu, rang 3; 0,1074; ... odlikovanje, rang 8;0,0927). Uočljivo je i da su razlike u vrednostima za ostale stimulativne mere rangirane od 2-8 male, a na dnu se nalaze nagrade knjigom (rang 9; 0,0668) i pohvale (rang 10; 0,0661) čije su vrednosti znatno niže od ostalih stimulativnih mera.

Dobijeni rezultati ukazuju da novčana primanja profesionalnih pripadnika nisu na potrebnom nivou i u skladu su sa temeljnom motivacionom teorijom hijerarhije potreba, [12] po kojoj su potrebe hijerarhijski ustrojene, a u motivaciji dominiraju nezadovoljene potrebe nižeg nivoa.

Analiza agregiranih vrednosti za svih 7 subpopulacija ispitanika pokazuje mala odstupanja. Novčana nagrada je na prvoj poziciji za sve subpopulacije, a mala su variranja rangova za ostale nagrade (nagrada knjigom 8-10, pohvala 9-10, odlikovanje 7-8, vanredno unapređenje 2-5, upućivanje na školovanje-kurs 3-6, besplatan boravak u odmaralištu 2-5). Najizraženije razlike u rangovima i vrednostima javljaju se u rangiranju nagradnog odsustva (2 za civilna lica, SSS i podoficire, a 8 za oficire i VSS), nagrade sabljom-pištoljem (3 za podoficire, 9 za civilna lica) i raspored na viši položaj (3 za oficire i 8 za podoficire i SSS). Po kategorijama najuočljivije su razlike za kategoriju civilna lica, civilna lica u odnosu na ostale grupe ispitanika znatno više vrednuju nagradno odsustvo i besplatan boravak u odmaralištu, a znato niže od ostalih ispitanika vrednuju nagradu sabljom-pištoljem (što je i razumljivo jer sablja-pištolj više simbolizuju vojnu profesiju) i odlikovanje.

\section{Zaključak}

U radu su prikazani rezultati istraživanja realizovanog na uzorku od 393 profesionalnih pripadnika Vojske Srbije u kome su ispitani stavovi profesionalnih pripadnika o motivacionom uticaju stimulativnih mera, o uticaju dodele stimulativnih mera na motivaciju za rad, uticaju stimulativnih mera na motivaciju za rad i radne rezultate u organizaciji, stavova o načinu dodele i o zasluženosti dodeljenih stimulativnih mera. Primenom statističkih testova, t-testa i $\mathrm{H}^{2}$ (chi-square) utvrđeno je postojanje statističke značajnosti utvrđenih razlika za različite kategorije ispitanika (oficiri-podoficir, SSS (srednja stručna sprema) VSS (visoka stručna sprema), rukovodioci-izvršioci).

Prikazani rezultati prikazuju da pripadnici Vojske Srbije na prvo mesto kao motivator stimulativnu meru postavljaju nezadovoljenu potrebu u vidu novčane nagrade, rangiravši je i postavivši je daleko ispred nagrade sabljom ili pištoljem sa posvetom, odnosno odlikovanja (tabela 8, slika 1 i slika 2), na začelju se nalaze kao najmanje poželjne knjiga i pohvala.

Nažalost, sistem stimulativnih mera u Vojsci Srbije, ne ostvaruje svoju punu funkciju i nema dovoljno izražen pozitivan uticaj na rad profesionalnih pripadnika Vojske Srbije. Profesionalni pripadnici Vojske Srbije smatraju da dodela stimulativnih mera nema veliki uticaj na motivaciju za rad: ocena uticaja na motivaciju za rad je mala $(A S=3,42)$, uticaj stimulativnih mera na motivaciju za rad u radne rezultate u kolektivu je veoma niska $(A S=2,58)$ dok je ocena zasluženosti stimulativnih mera takođe na niskom nivou (AS=2,94) pri čemu su nađene statistički značajne razlike za različite kategorije kadra (oficiri imaju pozitivnije stavove 0 zasluženosti stimulativnih mera od podoficira, a takođe i lica sa VSS od lica sa SSS). 
Primetno je da veći procenat ispitanika $(37,6 \%)$ ima negativne stavove o dodeli stimulativnih mera, a $19,3 \%$ ispitanika ima pozitivne stavove pri čemu su primenom $\mathrm{H}^{2}$ testa utvrđene statistički značajne razlike u različitim kategorijama ispitanika (ispitanici sa visokom stručnom spremom - VSS imaju pozitivnije stavove o zasluženosti dodeljenih stimulativnih mera u odnosu ispitanike sa srednjom stručnom spremom, a izražene su razlike i u stavovima oficira i podoficira). Pozitivne stavove o načinu dodele stimulativnih mera iskazalo je samo $14,5 \%$ ispitanika, dok negativne stavove ima čak $46,8 \%$ ispitanika. Takođe su utvrđene statistički značajne razlike u različitim kategorijama (VSS u odnosu na SSS i oficiri u odnosu na podoficire imaju pozitivnije stavove).

Na osnovu rezultata istraživanja možemo formulisati i određene preporuke na osnovu kojih se može povećati motivacioni uticaj stimulativnih mera:

- Poželjno je da se stimulativna mera dodeli neposredno po realizaciji zadatka ili posla za koji je zaslužena jer je tada očigledna i stimulativna i za nagrađenog i za ostale u kolektivu jer je jasno vezana za izvršenje, a ne da se vezuje za određene datume-praznike.

- Novčana nagrada mora imati dovoljnu visinu da bi bila privlačna i stimulativna, ali mora biti i dostižna i zavisiti od rada i rezultata rada, pojedinac mora da zna da može svojim radom da utiče na to da li će nagradu dobiti ili ne, a ne da na to utiču okolnosti i odobrena suma za novčane nagrade u nekoj organizacionoj celini ili trenutno stanje u budžetu Republike Srbije.

- Prilikom dodele stimulativnih mera potrebno je biti pravičan i pažljiv, dešava se da dodela stimulativne mere bude i izvor nezadovoljstva i demotivacije onih lica koja smatraju da su nagrade dobila lica koja to ne zaslužuju ili onih lica koja smatraju da su svojim trudom i zalaganjem ostvarili rezultate, a nisu dobila nagradu.

- Sistem dodele nagrada treba decentralizovati, potrebno je smanjiti ograničenja kako u vremenu primene, tako i u broju nagrada, potrebno je da sva lica imaju percepciju da svojim radom mogu dosegnuti neku od nagrada, a promene u sistemu dodele stimulativnih mera moraju se zasnivati na poznavanju uticaja pojedinih stimulativnih mera na određene strukture kadra.

\section{Literatura}

[1] Dugoročni plan razvoja sistema odbrane Republike Srbije, Beograd 2011.

[2] Strategijski pregled odbrane Republike Srbije, 2015.

[3] Alargić D.: Sistem vrednosti pripadnika Vojske Srbije u kontekstu reformi društva, Vojno de$10,5 / 2015$

[4] Doktrina upravljanja ljudskim resursima, 2012.

[5] Petz B.: Osnovne statističke metode, Izdavački zavod Jugoslavenske akademije znanosti i umjetnosti, Zagreb, 1974.

[6] http://www.endmemo.com/statistics/kurtosis.php.

[7] http://www.endmemo.com/statistics/skewness.php.

[8] Todorović D.: Metodologija psiholoških istraživanja, Centar za primenjenu psihologiju, Beograd, 2008.

[9] Milićević M.; Župac G.: Subjektivni pristup određivanju težina kriterijuma, Vojnotehnički glasnik, br. 2, 48-70, Beograd, 2012.

[10] https://www.mathportal.org/calculators/statistics-calculator/t-test-calculator.php.

[11] http://www.socscistatistics.com/tests/chisquare2/Default2.aspx.

[12] Maslow A.: Motivacija i ličnost, NOLIT, Beograd, 1982. 